\title{
BIT チョール（インド・ムンバイ）の形成とその現状に関する研究 A STUDY ON FORMATION AND PRESENT CONDITION OF BIT CHAWLS IN MUMBAI (INDIA)
}

\author{
池尻隆史*, 山田協太** \\ Takashi IKEJIRI and Kyota YAMADA
}

\begin{abstract}
The Bombay City Improvement Trust (BIT) was the public organization that took important roles in improvement and reconstruction of overcrowding city in early 20th century, Mumbai. The BIT provided "sanitary dwellings for the poor" and most of them, called BIT Chawls, are existing still now. We made classify the construction process of BIT Chawls by investigation on Administration Report. And also, we grasped present condition by field survey. BIT carried out 71 of improvement schemes, included 22 of construction of Chawls. Of these, we can find 19 cases of exsitence, now. We can find typology on structure system, floor planning, and so on.
\end{abstract}

Keywords: Mumbai(Bombay), City Improvement Trust, Chawl, Public Housing, Masss Housing, Colonial City ムンバイ (ボンベイ), 都市改善トラスト, チョール, 公共住宅事業, マスハウジング, 植民都市

\section{1. 研究の背景と目的}

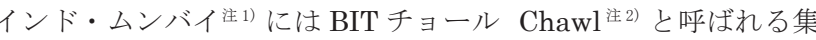
合住宅群が存在する。これらは 20 世紀初頭に当地の都市再開発・環 境整備事業を行った公的機関であるボンベイ改善トラスト（Bombay City Improvement Trust、以下 BIT と表記する) によって供給され たものであり、アジア地域において最も早い公的住宅供給事業の一 つと比定されるものである。

BIT の設立は 1898 年に遡る。BIT は植民地期のインドにおける都 市改善卜ラストとしては最も早く設立されたものであり、その後の国 内外に設立された同種の団体のモデルになった可能性が高い注3)。BIT チョールについても、その計画概念は各地のトラストの活動を通じ て受容され、公的集合住宅の先行例として引用された可能性がある。 英国植民地内での都市改善卜ラストによる住宅供給事業は、初期の 公共住宅における計画上の特徴を明らかにするものとして大きな意 味を持ち得る。

BIT の組織や活動に関しては、他の都市のトラストとあわせて、 様々な記録や著述が残されているが、一方で住宅供給事業を含む具 体的な事業の検証は進んでいない状況にある。また、ムンバイ市内 の各地には相当数の旧 BIT チョールが存続しているが、その現状に ついてのまとまった資料は存在していない。本論文は「ボンベイ改 善トラストによる住宅供給事業の展開とその影響に関する研究注4)」 と題する BIT チョールの形成と計画概念の伝播の様態に関する研究
の第一段階として、文献資料調查と現況調查に基づき、BITによる チョール供給事業の展開過程を明らかにすることを目的とする。

\section{2. 既往研究と本論文の位置づけ}

初期の BIT による住宅供給事業の展開については、同時代の研究 として A. R. Burnett-Hurstによる文献 (Hurst, 1925) がある。この 文献は、都市衛生環境の状態とこれを改善する BIT の活動について 多く言及しており、当時の状況を把握する上で重要なものと位置づ けられる。これと同様に、同時代に記録された BIT に関連する記録 としては地誌も参照可能である (Edwards, 1906)。S. B. Upadhyay による文献 (Upadhyay, 2004) は 19 世紀末から 20 世紀初頭のムン バイにおける綿工場の労働問題を扱うものであるが、労働者の居住 環境に関する議論で BIT の労働者向け住宅の供給に関する多くの 記述がある。同様に R. Chandavarkar の文献もムンバイにおける 産業化の過程を検証するもので、住宅問題に関する多くの記述を含 む(Chandavarkar, 1994)。近年の研究では、R. Kidambi が 19 世 紀末から 20 世紀初頭にかけてのムンバイの都市開発について論じ、 BITによる住宅供給施策についても多く言及している（Kidambi, 2007))。R. Mehrotra らによる一連の文献（Mehrotra, 1995 and 1997）は都市成立以降その拡大が本格化する 17 世紀末以降の都市 形成史を明らかにするものである。ここでは BIT による都市改善事 業に関してまとまった記述がある。同様に都市形成史については M.
* 千葉大学大学院工学研究科 助教 $\cdot$ 博士 (工学)

**京都大学大学院アジア・アフリカ地域研究研究科 助教・博士 $($ 工学
Assistant Prof., Graduate School of Engineering, Chiba University, Dr. Eng.

Assistant Prof., Graduate School of Asian and African Area Studies, Kyoto University, Dr. Eng. 
Konsabi による文献も重要である（Konsabi, 1986）。ただし、いず れの文献も具体的な BIT チョール事業地ならびに住宅そのものに関 する記述はほとんどない。

植民地における都市計画手法や建築類型の伝播に関しては R. Homeによる文献に多くの記述がある（Home, 1996）。BIT も含め、 植民地における住宅供給事業に関して多くの記述があり、特にムンバ イと香港の事例を取り上げて事業の類似性を指摘している。しかしな がら、具体的な事業内容や住居計画の詳細に関しては論じていない。

以上の通り、既往の研究では様々な範囲で BIT に関する議論を展 開しているが、一方で個々の事業や実際の住宅に関してはまとまっ た記述が存在していない。本論文ではこれを補うものとして、実際 の事業に就いて精查し、BIT チョール建設の歴史的な展開を整理す るとともに、現地調査を交えてそれらの存続状況を明らかにするこ とを目的とした。

\section{3. 研究方法}

\section{3-1 利用した資料について}

BIT の活動は、同団体の年次報告書 BIT Administration Report (参 考文献 1 ) 以下、年次報告書) に年ごとの活動実績が記録されている。 本論文では、BIT によるチョール供給事業の全体像を明らかにする 目的から、第一にこの資料を精查し、チョール建設に関わる歴史的 な事実の把握に努めた注5)。ただし、この報告書は事業の概要を紹介 するものであり、事業の詳細や実際の設計等に関する記録としては 不足している部分も多い。これらの点については、適宜関連文献よ り内容を増補した注6)。年次報告書以外の公的記録としては、同時期 の書簡類や図面類、また登記簿等の参照が考えられる。しかしながら、 これらの発見は困難であり、またいずれも系統的な保存が確認でき ない状況にある注7)。このため、これらについては入手できたものの 範囲で部分的な引用に留めた。

チョール事業地の確認には、MMRDAによる都市計画図を利用し た主8)。この地図上には既存の建物の形状が記入されており、各事業 地における住棟の配置形態が確認できる。BITレポート中の住棟の 数や形状に関しての記述を参考に、都市計画図上で事業地を割り出 し、記録した。判別が困難な事例については適宜 Google Earth®な どの Web 上の衛星地図サービスも利用している。

\section{$3-2$ 調査の概要}

本研究に伴って、BIT の年次報告書の調査を 2008 年 6 月ならびに 2009 年 6 月に行い、関連する記述を収集した（池尻）。

現地調查も同じく 2008 年から 2009 年にかけて行っている（池尻・ 山田)。資料調查に用いた地図はいずれも古く、また BITチョール
の現状に関する情報が限定的であるため、調査では第一にBIT チョ ールの所在を確認することを目的とした。存続が確認できたチョー ルについては、現状の記録をした。記録の対象としたのは主として 外観上の特徵に関するもので「住棟数・住戸数・階数・増改築の有 無・住戸や設備の配置」の 5 項目とし、同時に「改築計画の有無」 などの存続状況に関する情報も収集した。一部の事業地については、 2003 年時点での調查記録を参照している注9)。

\section{BITによる都市改善事業}

\section{4-1 都市改善事業の展開}

BIT は当時のボンベイ市当局によって 1898 年に設立された。設 立の直接の契機となったのは 1896 年のペストの大流行である。当 時のボンベイはすでにインド最大の産業都市であり人口の過密によ る衛生環境の深刻な悪化が問題となっていた。そのためペストの流 行は都市に大きな被害を与えている（Home, 1996, p74）注10)。BIT は既存市街地に抜本的な再開発を施すことで、都市環境を改善させ る目的で設立された注 11)。設立当初の年次報告書には、同団体設立の 目的が次のように示されている（BIT, 1898）注 12)

1 ）新規街路の建設

2 ）過密居住地の除去

3 ）埋立てによる市街拡大用地の確保

4 ）貧困層向けの衛生的住宅の建設

以降、BIT はボンベイ市より大規模な土地の付託を受け、早々に 都市改善事業を展開している注13)。BIT は 1933 年に市政府に吸収さ れるまで、71 件の都市改善計画を立案し実施した。年次報告書に記 載されている全事業より主要なものを表 1 に示す。

BIT の事業はそれぞれ固有の事業番号を有する。事業内容につい ては、既存市街地の改良と郊外における居住地区開発が大きな柱と なる。既存市街地の改良においては、ネイティブタウンを中心とし た衛生状態の悪い密集地帯に対して、新規の大規模街路を建設して 交通網の整備と同時に通風・採光の確保を企図した計画が多い。新 設街路に沿って区画整理を行い、賃貸供給すると共にチョール事業 地を設定して面的な開発も行っている。都心であるフォート地区に おいても区画整理や造成の実績がある注 ${ }^{14)}$

一方で、郊外においては市街化していない地域に街路を敷設し、 新たに開発用地を整備している。ボンベイ島中心部のアグリパーダ 地区 ${ }^{\text {15) }}$ や北部のパレルからシオンに至る広大な領域注 16) は、いずれ もBITによって開発されたものである。

BIT の事業では警察官官舎 Police Accommodation の建設が特徵 になる。これは当時の警察機構の整備に伴うもので、市内各地に積

表 1 BIT による主要な都市改善事業

\begin{tabular}{|c|c|c|c|}
\hline 事業番号 & 名称 & 事業期間 & 事業の概要 \\
\hline 1 & 1st Nagpada & 1898-1912年, 1930年 & ネイティブタウンの密集地带の改善・チョールの供給 \\
\hline 2 & Princess Street & 1898-1914年, 1928-30年 & ネイティブタウン南端部における新規街路建設 \\
\hline 3 & Sandhurst Road West & 1898-1919年， 1927-29年 & $\begin{array}{l}\text { ネイティブタウン中央部における大規模東西街路の建設 } \\
\text { 区画整理の実施と仮設住宅ならびにチョールの供給 }\end{array}$ \\
\hline 5 & Dadar-Matunga & 1898-1930年 & 郊外における新規街路の建設と新規区画整理 \\
\hline 6 & Sion-Matunga & 1898-1929年 & 住宅建設 \\
\hline 7 & Colaba Reclamation & 1902-14年, 1930年 & コラバ地区南部における海面の埋立ておよび区画造成 \\
\hline 22 & Hornby Road & 1903-09年 & フォート地区における区画造成 \\
\hline 29 & Nowroji Hill & 1906-30年 & 乓陵地帯の造成、街路とチョールの新設 \\
\hline 31 & Parel & 1910-30年 & 郊外における南北街路の整備とチョール建設 \\
\hline 37 & Sydenham Road & 1914-15年, 1926-30年 & ネイティブタウンにおける街路新設と関連する区画整理 \\
\hline 43 & Parel Road (Central) & 1926-30年 & ネイティブタウンから郊外（パレル地区）に至万街路の建設 \\
\hline 47 & Parel Road (Northern) & 1923-30年 & \\
\hline
\end{tabular}

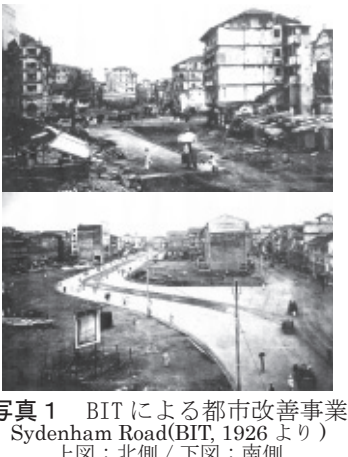

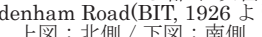


極的に建設された。事業数は全事業数の $1 / 3$ 程度を占めている。警 察官官舎は基本的に街路計画や市街地改良とは別に独立した事業と なっている例が多い注 17 。

各事業の開始時期に関しては、設立以降 1905 年頃までが最も多い。 1925 年頃までにほとんどの事業が着手されており、以降の新規事業 は少ない。

\section{4-2 BIT チョールの建設}

年次報告書より集計した BIT の全事業のうち、チョールの建設が確 認できるものを抽出した。BIT は解散する 1933 年までに 22 箇所で チョールの建設を計画し、少なくとも 1 万戸以上の住戸を供給したこ とが読み取れる注 18)。表 2 に確認できたチョール事業地の一覧を示す。 年次報告書中の記述から確認できる BIT チョールの特徴は以下の ように要約できる。

1) 建設目的について

BIT の活動の初期においては、チョール建設は既存不良住宅地区 の改善に伴う代替住宅供給事業として規定されている。供給の対象 としたのは、再開発事業で住居を失う貧困労働者層注 19$)$ であった。 代表的な例としてはナグパーダ Nagpada の 2 チョール（ナグパー ダ $\mathrm{A}$ および B)、アグリパーダ Agripada の 3 チョール（アグリパ ーダ A, B, C)、ならびにイマームワダ Imamwada の 2 チョール（イ マームワダ A および B）が挙げられる。マンドヴィ=コーリーワダ Mandvi-Koliwada とチンチバンダル Chinch Bundar の事例も既存 市街地改善事業に分類できるが、これらについては一階部分を明確 に商店ないしは倉庫と規定し、店舗賃貸事業も合わせた計画となっ ている注20)

次に登場するのが、工場チョール Mill Chawl である。これは文 字通り工場労働者を対象に衛生的住宅を供給するもので、慢性的な 都市の住宅不足やこれに対応した無秩序な住宅建設の拡大を防ぐ目 的のものであった。工場チョールの建設においては、BIT は工場 主に一定の負担を求めており、長い期間をかけて折衝が行われた (Upadhyay, 2004, pp72-79) 注21)。BIT が主体的に計画し得た代替住 宅事業と異なり、工場チョールにおいては工場主との交渉というプ ロセスを要したために建設の認可に至るまでの過程が複雑化してお り、この点が特徵と位置づけられる。工場チョールの初めての事例 はスプリングミル Spring Mill チョール（1918 年竣工）である。

この他にはジャイナ教徒向けの住宅として計画されたラブレーン の事例やマハール・コミュニティー注22) を対象としたマハールチョ
ール Mahar Chawl の事例がある注23)。また、ピオンズ Peon's チョ ール はトラストの従業員住宅として計画されたものである注24)。 のような特定の居住者に向けた住宅供給が行われている点も、BIT によるチョール事業の特徴の一つと位置づけられよう。

2 ) 住棟・住戸の仕様について

報告書にはいくつかのチョールについて主体構造注 25) に関する記 述が残っている。ここでは初期の段階から住宅の RC 化に関して議 論されており、構造形式における新技術導入の検討は BIT チョール の特徴の一つと位置づけられる。 $\mathrm{RC}$ 造による建設事例であること が初めて明記されているのは 1910 年竣工のマンドヴィ=コーリー ワダチョールである注26)。以降のチョールについては、構造種に関す る記述がないものも多いが、記述が残っているものについては全て RC 造と表記されている。

住戸の基本構成は「居室 Living Room」と「ベランダ Verandha」 としており、居室の規模については 8 フィート $\times 10$ フィート、ない しは 9 フィート $\times 12$ フィートという基本単位に関する記述がある。 ただし、このような空間単位に関する記述はごく限られたものでし かなく、全体像や形態の変遷については必ずしも明確ではない。衛 生環境の改善に直接関係する水廻りや便所などの設備に関しても具 体的な記述に乏しい。報告書中には、BIT チョールの平面図 3 点と 立面図・断面図各 2 点の収録が確認できる（図 1 ）。これらで共通す る特徴は、以下の三点である。

・平面計画において中廊下型の住戸配置を示していること

・共用の水仕事場と便所 Latrine が集中的に配置されていること

・特に便所については住戸と明確に区分されて集約されていること

\section{4-3 BIT チョールの評価}

BITチョールの建設が「労働者階級ならびに貧困層向けの住宅供給」 を目的としたことは前述した通りである。これらの住宅供給事業の成 果についても、年次報告書中に度々言及されている。特に記述が多 いのは、ナグパーダやアグリパーダ地区における初期の過密居住地 の改善を目的に供給されたチョール群に関するもので、いずれも建 設したチョールが地区の環境改善に果たした成果を示寸記述が多い。 主として分析の対象とした指標は死亡率の推移で、アグリパーダ $\mathrm{A}$ および B チョールでは 1906 年から 1907 年の間におよそ半減してい ることが示されている注27)。チョールの建設前後での死亡率の変化に 関しては、これが当時のボンベイ市域の $1 / 3$ から $1 / 4$ の水準に低下し たことを伝える記述がある（Hurst, 1925, p26）注28)。

表 2 建設されたBIT チョールの一覧

\begin{tabular}{|c|c|c|c|c|c|c|c|c|c|}
\hline \multirow{2}{*}{ チョール名称 } & \multicolumn{2}{|r|}{ 事業 } & \multicolumn{6}{|c|}{ チョールの概要 } & \multirow{2}{*}{ 備考 } \\
\hline & 番号 & 名称 & 着工年 & 竣工年 & 棟数 & 階数 & 戸数 & 構造 & \\
\hline \begin{tabular}{l|l} 
Agripada A \\
\end{tabular} & & 1st Nagpada & 1899 & 1901 & 4 & 3 & 294 & レンガ造 & 当初計画では6棟であった模様 \\
\hline 2 Nagpada A & & 1st Nagpada & 1903 & 1905 & 2 & 4 & 144 & レンガ造 & 当初計画ではRC造の予定 \\
\hline 3 Agripada B & & 1st Nagpada & 1903 & 1905 & 12 & 4 & 928 & レンガ造 & 当初計画ではRC造の予定/1910年にベランダをコンクリートに変更 \\
\hline 4 Chandanwadi & & Sandhurst Road West & 1905 & 1908 & 6 & 4 & 678 & 記載なし & 1929年にベランダ部分を改修 \\
\hline 6 Imam Wada A & & Sandhurst Road West & 1905 & 1910 & 6 & 4 & 876 & 記載なし & 1908年に5棟竣工/総住戸数は883戸の可能性あり \\
\hline 7 Mandvi-Koliwada & & Mandvi-Koliwada & 1908 & 1910 & 2 & 4 & 232 & $\mathrm{RC}$ & 1909年部分完成/他に店舗30戸・倉庫27户を併設 \\
\hline 8 Nagpada B & & Sandhurst Road West & 1909 & 1910 & 1 & 4 & 144 & $\mathrm{RC}$ & Nagpada Aに隣接する敷地に建設された \\
\hline \begin{tabular}{l|l} 
Agripada C \\
\end{tabular} & & Sandhurst Road West & 1909 & 1911 & 6 & 4 & 432 & $\mathrm{RC}$ & 1910年部分完成 \\
\hline 10 Suparibag & & Parel & 1910 & 1911 & 6 & 4 & 480 & $\mathrm{RC}$ & 1910年部分完成 \\
\hline 11 Imam Wada B & & Sandhurst Road West & 1911 & 1912 & 1 & 2 & 30 & $\mathrm{RC}$ & イマームワダ地区では初めてのRC造チョール \\
\hline 12 Chinchi Bundar & 29 & Nowroji Hill & 1913 & 1917 & 6 & 4 & 384 & $\mathrm{RC}$ & 1916年までにほぼ完工/戸数は推計(1棟あたり64戸という記述より) \\
\hline 13 Spring Mills & & Spring Mills & 1915 & 1918 & 8 & 3 & 記載なし & $\mathrm{RC}$ & 局数は推計/建築材料（コンクリート・鉄鋼） の調達に関する記述あり \\
\hline 14 Mahar & & East Agripada & 1919 & 1920 & 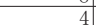 & L & 320 & $\mathrm{RC}$ & マハールコミュニティの住宅として計画されたもの \\
\hline 15 Karapani & & East Agripada & 1919 & 1920 & 記載なし & 記載なし & 240 & $\mathrm{RC}$ & ムスリムコミュニティの住宅として計画されたもの \\
\hline 16 Peon's Chawl & & East Agripada & 1919 & 1920 & 記載なし & 記載なし & 120 & $\mathrm{RC}$ & BIT職員向け住宅として計画されたもの \\
\hline 17 Mazagaon & 50 & Mazagaon Street & 1920 & 1922 & 15 & 記載なし & 1280 & $\mathrm{RC}$ & 1921年部分完成 \\
\hline 18 Foras Road & 53 & Foras Road & 1920 & 1922 & 19 & 記載なし & 1520 & $\mathrm{RC}$ & 1921年部分完成/320戸は2部屋タイプ/竣工戸数は1504室の可能性あり \\
\hline 19 Kohinoor Mills & 60 & Naigaum & 1920 & 1922 & 記載なし & 記載なし & 約500 & $\mathrm{RC}$ & 計画時はすべて2部屋タイプだったが、後に618単室+183複室へ変更 \\
\hline 20 Love Lane & & Love Lane & 1922 & 1924 & 記載なし & 記載なし & 866 & 載なし & 1923年に779室に規模縮小/ジャイナ教徒向け \\
\hline 21 Century Mills & & Century Mills & 1917 & 記載なし & 記載なし & 記載なし & 記載なし & 記載なし & 1919年に着工というう表記もあるが以降の記述がない \\
\hline 22 David Mills & & David Mills & 記載なし & 記載なし & 記載なし & 記載なし & 記載な & 苞載な & 設計・施工に関する記述は確認できず \\
\hline
\end{tabular}



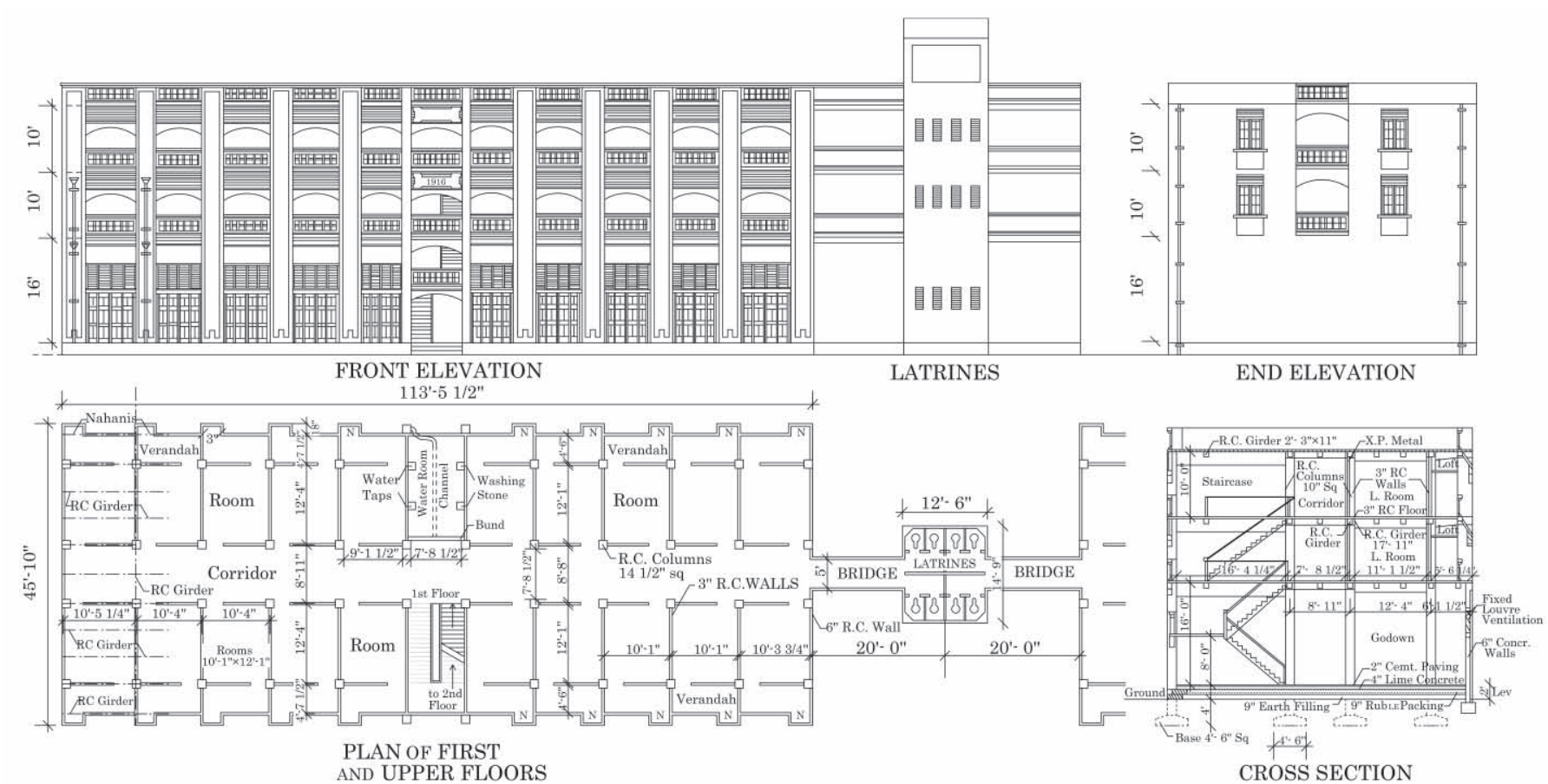

図1 年次報告書に収録されている BIT チョールの図面の一例（チンチバンダル・チョール、年次報告書（1917 年）より作成）

BIT の住宅供給実績については、BIT 自身による報告書の他に、 前述した様々な文献がその成果について言及している。多くの場 合、BIT が不良住宅地区の改善を進行させたことが強調される一方、 BIT チョールが代替住宅としては必ずしも有効でなかったことが示 されている注29)。工場労働者向けの住宅事業にしても、数が十分でな く、また工場主との連携に問題があり効果は限定的なものであった ことが示されている注30)。また、工場労働者住宅の建設に関しては、 新たに市当局の関与もあり、BIT が果たした役割は限定的であった 可能性がある注 31 。ここように、BIT の実績に対する評価については、 改めて検討すべき余地も多い。

\section{BIT チョールの現状}

\section{$5-1$ BIT チョールの分布}

年次報告書を基に、都市計画図を用いて BIT チョールの所在を確 認した。これを基に現地踏査を行い存続状況を確認している(図 2 )。 BIT チョールは密集市街地の改善事業に伴うものと工場労働者用住 宅の 2 種類が中心となるが、前者は都心より 3 から $5 \mathrm{Km}$ 、後者は 6 から $8 \mathrm{Km}$ の範囲に集中している注 32$)$ 。建設の経緯が明らかである BIT チョールのうち、所在が確認できなかったものは図 2 中(16 ピオ ンズの事例のみであった注 33 。

\section{5-2 各チョール事業地の存続状況}

表 3 に現存するBIT チョールの一覧を示す。前述の通り、ほと んどの BITチョールが現在も存続する一方、それらの多くにおい て再開発計画が進行しつつある。特にアグリパーダ地区では実際 に工事が始まっており、アグリパーダ B チョールはすでに半数が

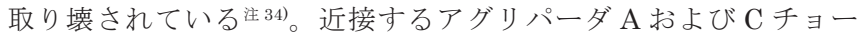
ルについても、数年内の取り壊しが決定している。同様に数年内 に取り壞される予定のチョールとしてはイマームワダ地区の BIT チョールが挙げられる注35)。その他の事業地おいても開発業者の活 動は活発な模様で、建て替え問題が各地で喫緊の検討課題となっ ていることが示唆されている注36), 注37)。

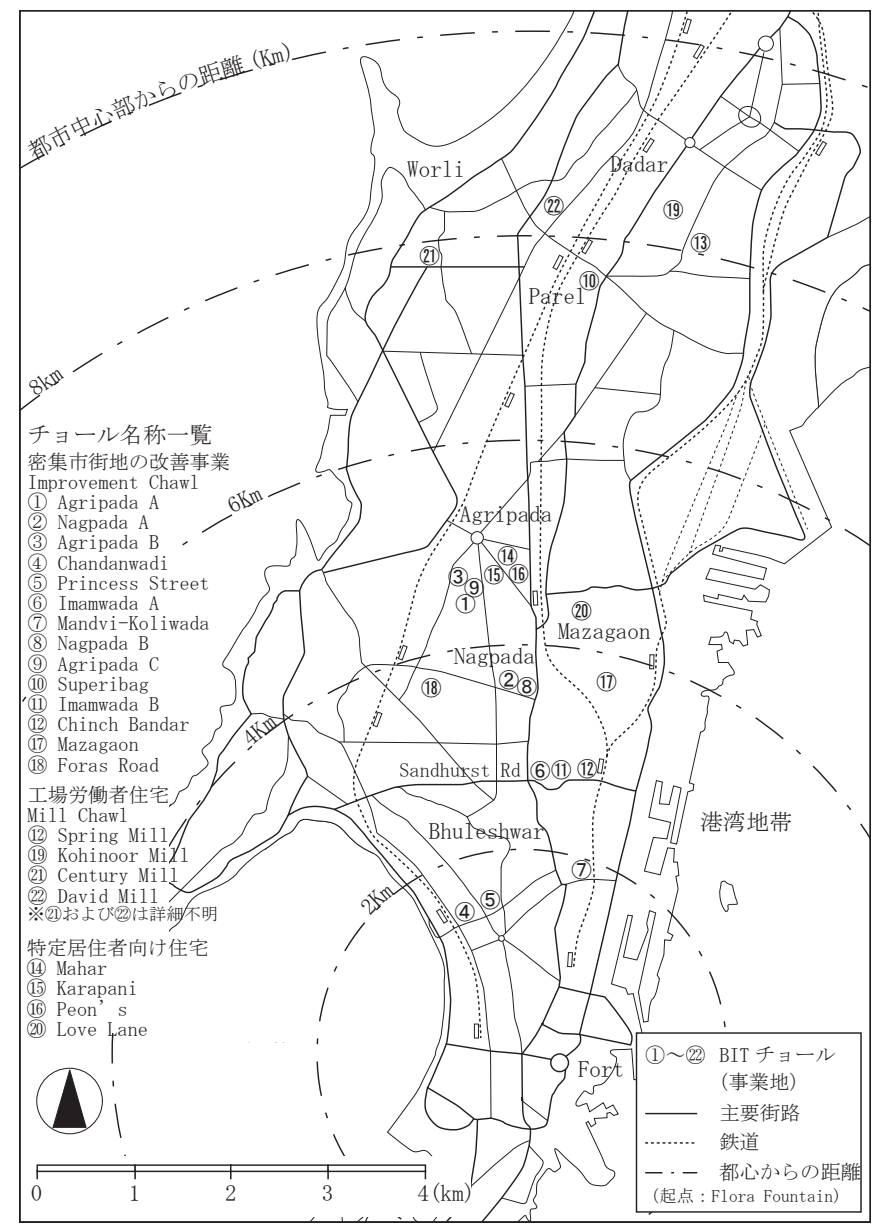

図2 BIT チョールの分布

\section{$5-3$ 住棟の特徵}

4-2 で述べた通り、報告書中では住棟・住戸に関して、構造形 式と平面計画の一部が記述の対象となっている。これらのうち、詳 細の不明な点については現地調査を基に補った。 
現存するすべての BIT チョールの構造種を確認した結果、報告 書中に記述のない 4 例のチョールのうち、初期の 3 例はいずれも 主体構造がレンガ造注 38) であり、末期のラブレーン Love Lane $の$ 事例はほぼ全体が RC 造であることが確認された。これは BIT チ ヨールの構造種については、1910 年のマンドヴィ=コーリーワダ における初めての $\mathrm{RC}$ 造の導入以降、一貫して $\mathrm{RC}$ が採用されて きたことを示す。
平面計画においては、住戸の配置と便所の形式に特徵が確認で きる。現存する BIT チョールの住戸配置は基本的に中廊下型とな っていた。例外はイマームワダ B チョールとコーヒヌール・ミル Kohinoor Mill チョールであり、これらは片廊下型となっている注39)。 報告書収録の平面図において、共用の水仕事場の設置と便所棟の分 離といった衛生設備の整備が特徴となっていることは前述の通りで ある。現状からはこの形式（表中では「別棟・集中」と表記）の他に、

表 3 現存するBIT チョールの一覧

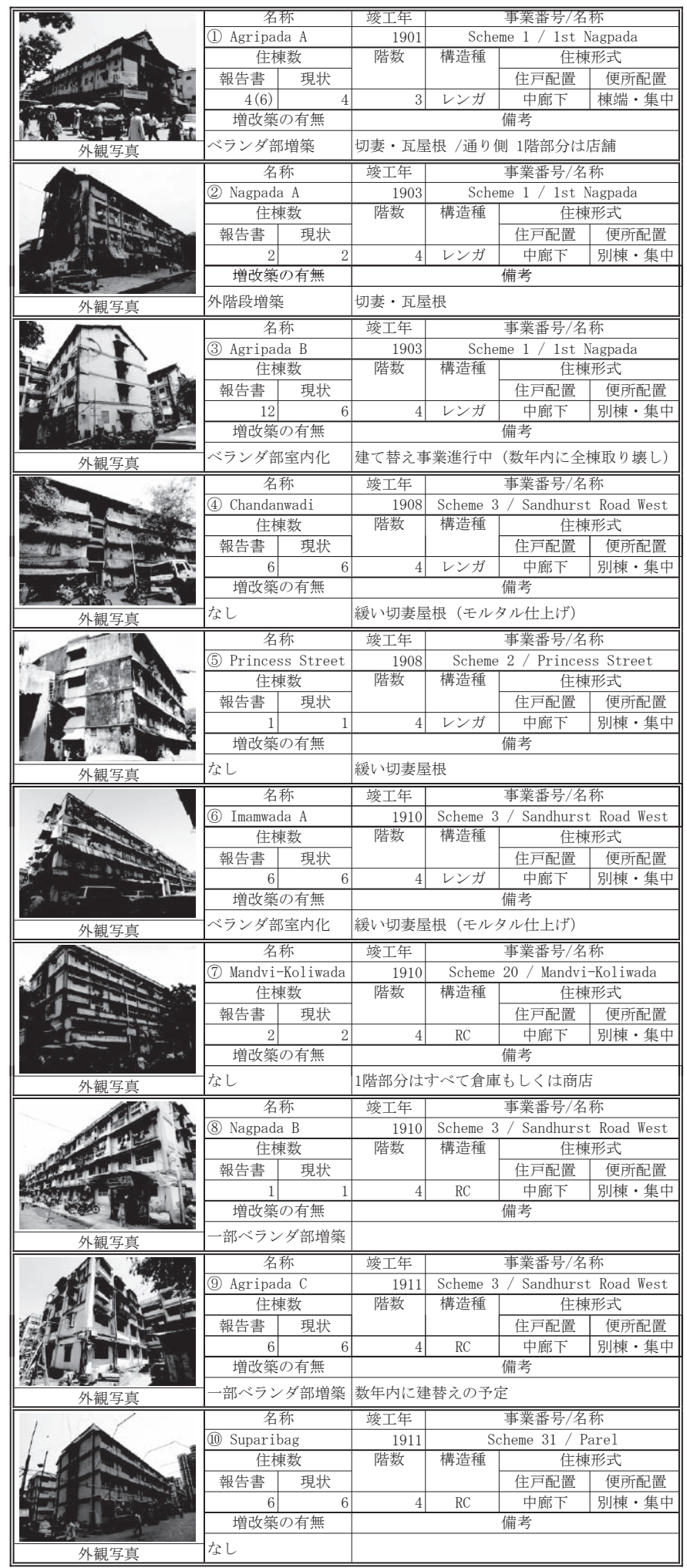

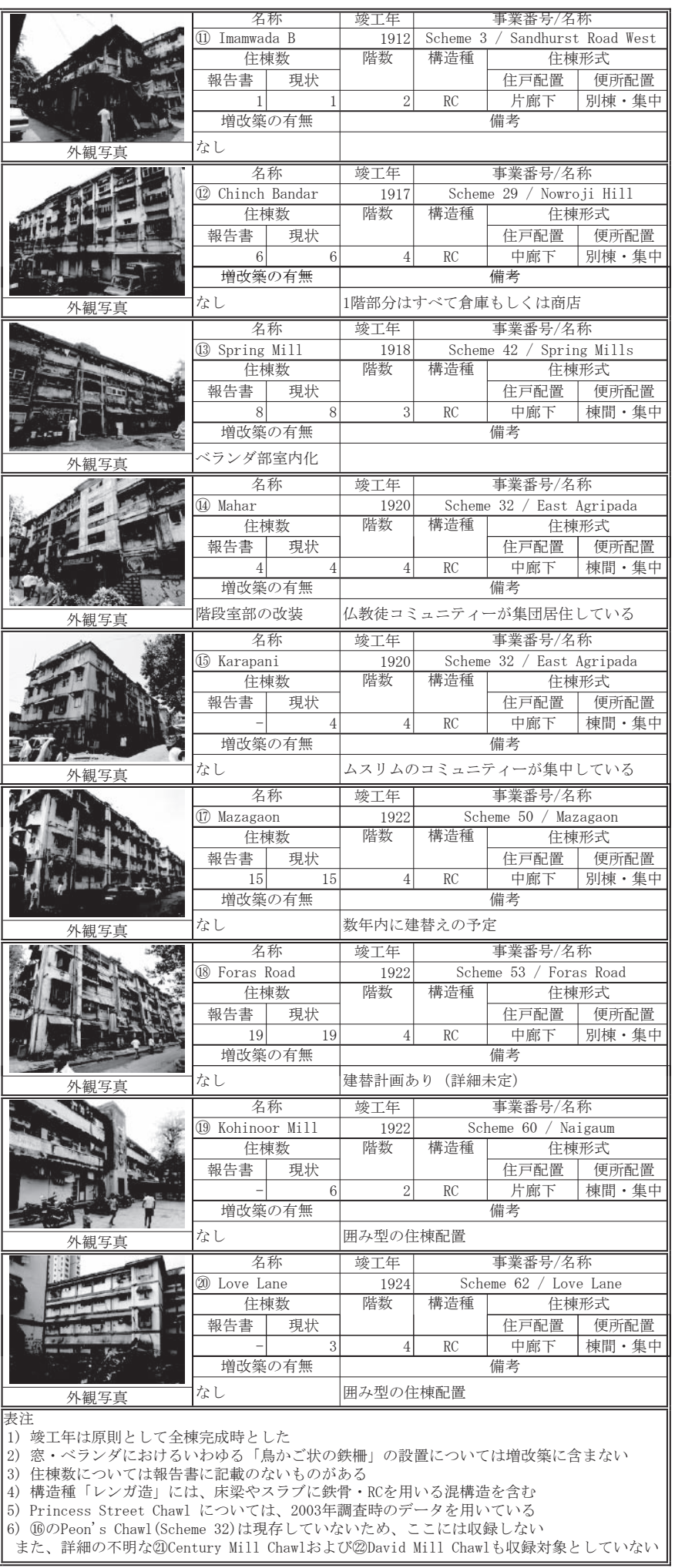




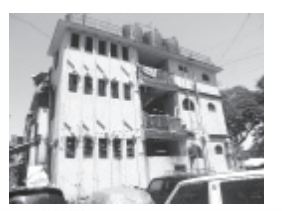

$\stackrel{3720}{+3}$

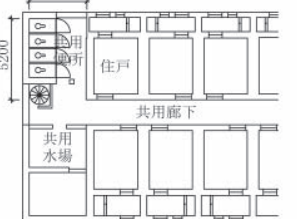

「棟端・集中」型アアクリハーダ

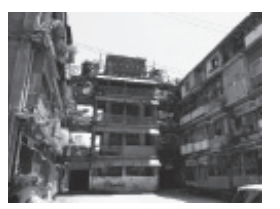

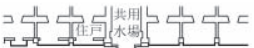

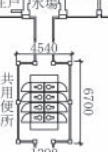

通路

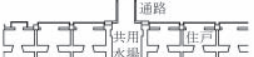

「別棟・集中」型・アリンーー

図 3 便所の配置形態
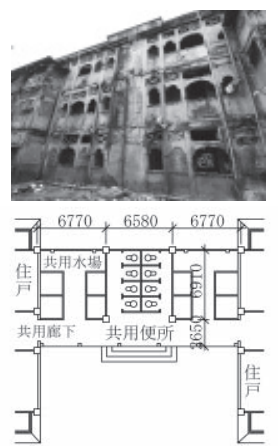

「棟間・集中」型 スプリンタジ

住棟間に住棟と構造的に連続した便所部を設けるもの（表中「棟間・ 集中」）が確認された。最初の BIT チョールであるアグリパーダ $\mathrm{A}$ のみ異なる形式を採用しており、棟端に便所を集中的に配置してい る(表中「棟端・集中」)。それぞれの外観を図 3 に示す。現状から「棟 間・集中」型の便所は 1918 年のスプリング・ミルが最初の事例と 比定され、以降のチョールは基本的にこの形式を採用している。こ れは住棟形式の変遷上の特徴の一つと位置づけられる注 40)

\section{$5-4$ 住棟の配置}

現地調查を基に、現存する BIT チョールの住棟配置を前出の都市 計画図上で示す (図 4 )。

図中に示すとおり、住棟配置に関しては明確な街区を形成する「街 区型」と街路に沿って建設される「街路型」に大きく二分できる。「街 区型」の中ではさらに 6 例が住棟の平行配置を採用しており、最も一 般的なものと位置づけられる。この類型では、他に囲み型の配置や両 者の複合型も見られた。「街路型」の多くは住棟を街路沿いに直列に 配置するが、こちらについても囲み型やその複合型が確認できる注41)。
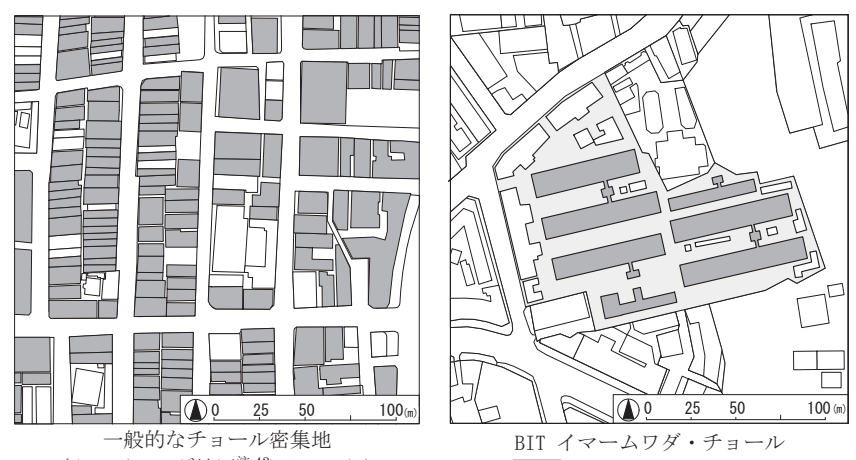

図 5 チョールの配置形態の比較

いずれの類型においても、隣棟間隔が広く取られていることが特 徴であり、民間開発のチョールや周辺市街地とは大きく異なる構成 を取っている (図 5 ) 注 42)。民間のチョールにおいては、隣棟間隔は ほとんどの場合考慮されていない。通風や採光は廊下や階段室から 確保する場合も一般的である。

\section{BIT チョールの変遷}

これまでに述べた報告書と現状に関する調査結果から、BIT チョ ールの変遷を整理した（表 4$)$ 。

時系列上で観察した場合、明確な変化が指摘できるのは構造種と 便所の配置である。構造種については、前述の通り 1900 年代初頭 にすでに検討の形跡があるが、実際の切り替えは 1910 年と初めて のチョール建設より 10 年を要している。便所の配置は住棟の平面形 式の上で大きな変化であるが、これは 1918 年と比較的遅い。この 変化について理由を明らかにす心゙く別途報告書等を精査したが、明 確な記述は存在しておらず、詳細については不明である。

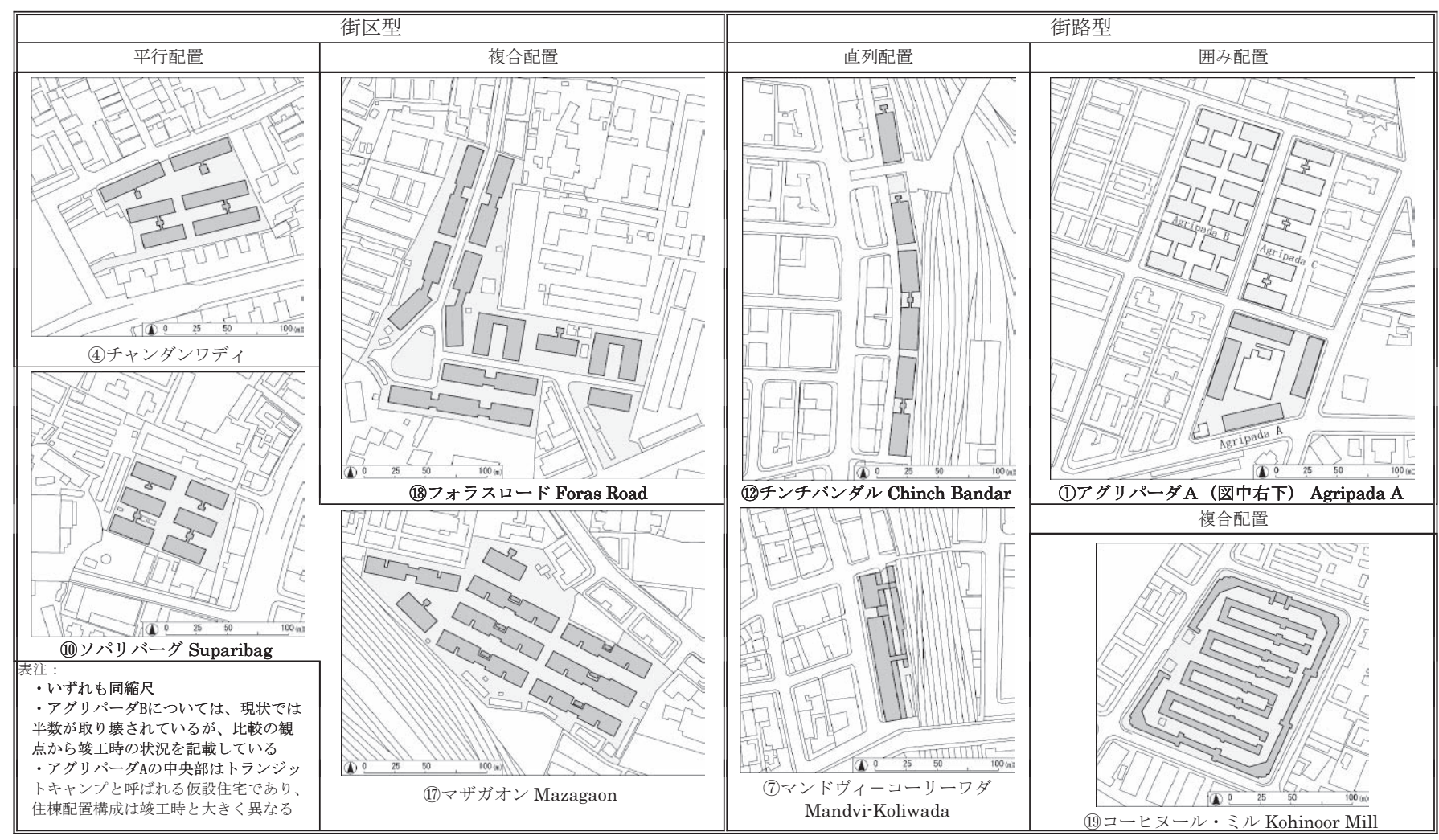

図4 BIT チョールの住棟配置類型 
表 4 BIT チョールの変遷

\begin{tabular}{|c|c|c|c|c|c|c|c|c|c|c|c|c|c|c|c|c|c|c|c|c|}
\hline \multirow{2}{*}{\multicolumn{2}{|c|}{ 住梾粸型 }} & \multicolumn{19}{|c|}{ 变工年 (1901-1924) } \\
\hline & & 01 & 05 & 08 & & \multicolumn{3}{|c|}{10} & 11 & & 12 & 17 & 18 & & \multicolumn{2}{|l|}{20} & & \multicolumn{2}{|c|}{22} & \multirow{3}{*}{\begin{tabular}{|l|}
24 \\
$\bullet$
\end{tabular}} \\
\hline 住 & 中漓下型 & \multirow{2}{*}{$\frac{01}{0}$} & \multirow[t]{2}{*}{ - } & \multirow{2}{*}{\multicolumn{2}{|c|}{0}} & \multirow[t]{2}{*}{ e } & - & - & & \multirow[b]{2}{*}{ - } & \multirow[t]{2}{*}{ - } & \multirow[t]{2}{*}{ - } & \multirow[t]{2}{*}{ - } & - & & \multirow[t]{2}{*}{$\bullet$} & . & & \\
\hline $\begin{array}{l}\text { 配 } \\
\text { 置 }\end{array}$ & 片原下型 & & & & & & & & & & & & & & & - & & & - & \\
\hline \multirow[t]{3}{*}{ 便 } & 別楝 & & \multirow[t]{3}{*}{ - $\bullet$} & & \multirow[t]{3}{*}{ - } & \multirow[t]{3}{*}{ e } & \multirow{3}{*}{\multicolumn{2}{|c|}{ - }} & \multirow{3}{*}{\multicolumn{2}{|c|}{ - }} & \multirow[t]{3}{*}{ - } & \multirow[t]{3}{*}{ - } & \multirow{3}{*}{ - } & \multirow{3}{*}{9} & \multirow{3}{*}{ - } & & & & & \\
\hline & 棟間 & & & & & & & & & & & & & & & - & - & - & - & - \\
\hline & 梀端 & - & & & & & & & & & & & & & & & & & & \\
\hline 棰 & レンガ造 & - & - $\bullet$ & & & - & & & & & & & & & & & & & & \\
\hline 種 & $\mathrm{RC}$ 造 & & & & & & - & - & - & - & - & - & - & - & - & - & - & - & - & - \\
\hline & 平行 & & - $\bullet$ & - & & - & & - & - & & $\bullet$ & & & & - & & - & & & \\
\hline 槽 & 複合 & & & & & & & & & & & & & & & & & - & & \\
\hline 配 & 直列 & & & & & & - & & & & & - & & - & & & & & & \\
\hline & 田孙 & - & & & & & & & & & & & - & & & - & & & & - \\
\hline & 複合 & & & & & & & & & & & & & & & & & & e & \\
\hline 建 & 改善チョール & $\bullet$ & - $\bullet$ & - & $\bullet$ & - & - & - & $\bullet$ & - & $\bullet$ & e & & & & & & - & & \\
\hline 設 & 工場チョール & & & & & & & & & & & & - & & & & & & - & \\
\hline & その他 & & & & & & & & & & & & & - & - & e & & & & - \\
\hline & チョール名称 & $\begin{array}{l}\text { 丞 } \\
\text { 总 }\end{array}$ & 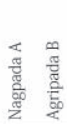 & 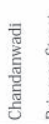 & 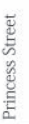 & 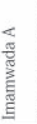 & $\frac{\pi}{8}$ & $\frac{\pi}{7}$ & 嘈 & 这 & 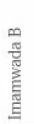 & 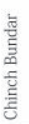 & 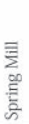 & $\frac{\sqrt{\frac{n}{5}}}{\frac{5}{2}}$ & 总 & & & & & 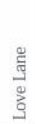 \\
\hline
\end{tabular}

建設目的については 1917 年が一つの転換点であり、従来の密集 市街地改善・再開発から工場労働者向け住宅の建設など多様な形態 を取るようになったと読み取れる。

住棟配置に関しては、平行配置を取るものが多い。時系列上では この平行配置を基本としながらも、時期を問わず様々な形態を取っ ていると読むのが妥当であろう。BIT チョールの配置形式はおそら くそれぞれの敷地の形状に依存するもので、形態の歴史的な変遷を 読み取ることは困難である。

住戸配置は基本的に中廊下型で一貫しているとして良い。しか しながら一方で、片廊下型の形式が、中期以降数度にわたって採 用されていることは注目に值する。特にこの類型では最後に建設 されたコーヒヌール・ミルの事例は500 戸以上というある程度ま とまった規模を持つものであり、このような計画になった経緯に ついては、改めて検証する必要がある注44)

\section{7. 結論と課題}

本論文を通じて明らかとなった BIT チョールの建設過程と建築的 特性、ならびに現在における存続状況については、以下のように要 約できる。

(1) BIT は 1898 年の設立から 1933 年の解散に至るまで、 71 件の 都市改善事業を展開しているが、その過程で 22 件のチョール建設 を計画している。このうち、計画から竣工に至る経緯が明確に記録 されているものは 20 件あるが、その大部分は現在も存続しており、 BIT チョールという名称で市内各地に点在している。

(2) BIT チョールは建設目的に着目した場合、既存不良市街地の改 善事業に伴う改善チョール、工場労働者向けの工場チョール、さら に宗教集団など特定コミュニティー向けのチョールなどに分類する ことができる。工場チョールに関しては、工場主やその団体との折 衝を伴うなど、建設過程が通常の改善チョールとは異なる。

(3) BIT チョールの基本的構成は中廊下型の住戸配置と住戸部分と明 確に区分された便所設備という形式に要約できる。構造形式は初期 においてはレンガ造であったが、1910 年に RC 化され、以降は一貫 して RC 造が採用されている。他に住棟の形態上の変化としては便所 設備の分棟化などが確認できるが、いずれの形態においても住戸と

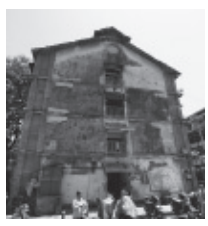

初期のレンガ造の事例 アグリパーダ B $(1905)$

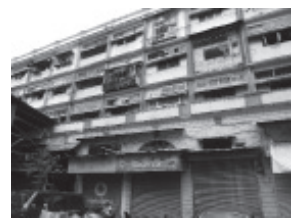

$\mathrm{RC}$ 造による最初の事例

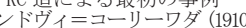
写真 2 BIT チョールの変遷

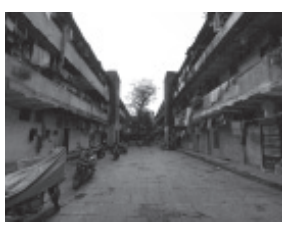
片廊下型の工場チョール
コーヒメール・
衛生設備は明確に区分され、原理的には一貫している。

(4) BIT チョールの住棟配置はさまざまな形式を取るが、最も多く の事例が存在するのは平行配置のものである。ただし、いずれの形 態の場合も隣棟間隔が広く確保され、周辺の一般的なチョールとは まったく異なる形式となっている点が特徴となる。

本論文では、BIT チョールの形成過程と現在の存続状況を明らかに することを目的としており、住戸レベルの詳細な調查・分析を行っ ていない。これらを踏まえた BITチョールの計画概念の再検証が今 後の課題となる。前述したとおり、BITチョールを含むムンバイの かつての都市郊外地域では、既存建物を取り壊して高層住居を建設 する再開発事業が極めて活発に行われている状況である注 45)。現存す る BIT チョールについてもいくつかについては数年内に消滅し、残 るものについても今後存続する可能性は低い。BIT チョールの図面 類については、所在が明らかでないものが多く、実測による資料収 集は極めて重要な価值を持つ。その意味で、現状の記録は喫緊の課 題と位置付けられる注46)

さらに、BIT チョールは現地において歴史的建築遺産として認識さ れていない状況にある注 47)。今後の維持や保全に関しては慎重な議論 が必要であるが、少なくとも記録の作成と現地への情報の還元は重 要な課題となり得る。

\section{参考文献}

1) Bombay Improvement Trust: Administration Report, City of Bombay Improvement Trust, 1899-1933 (全 36 分冊)

2) Burnett-Hurst, A. R.: Labour and Housing in Bombay, A study in the economic conditions of the wage-earning classes in Bombay, P. S. King \& Son LTD, 1925

3) Edwards, A. M.: The Gazetteer of Bombay City and Island, Vol. 1-3, Cosmo Publications, 2001(Original in 1906)

4) Upadhyay, S. B.: Existence, Identity and Mobilization, The cotton millworkers of Bombay, 1890-1919, Manohor Publishers, 2004

5) Chandavarkar, R.: The origins of industrial capitalism in India, Business strategies and the working classes in Bombay, 1900-1940, Cambridge University Press, 1994

6) Kidambi, P.: The Making of an Indian Metropolis, Colonial governance and public culture in Bombay, 1890-1920, Ashgate, 2007

7) Dwivedi, S. \& Mehrotra, R.: Bombay, The Cities within, India book house, 1995

8) Rouline, P., Godrej, P., Mehrotra, R.: Bombay to Mumbai, Marg Publications, 1997

9) Konsabi, M.: Bombay in Transition, The growth and social ecology of a colonial city, 1800-1890, Almqvist \& Wiksell Intl., 1986

10) Home, R.: Of Planting and Planning, The making of British Colonial cities, E \& FN Spon, 1996.

11) Maharashtra Economic Development Council: Fact-Book on Mumbai, BOMBAY First, 2000

12) Heitzman, J.: The City in South Asia, Routledge, 2008

13) Shaw, A.: The Making of Navi Mumbai, Orient Longman Pvt. Ltd., 2004 
14) Jacquemin, A.: Urban Development and New Towns in the Third World, Lessons from the New Bombay experience, Ashgate, 1999

15) Castells, M., Goh, L., Kwok, R Y-W.: The Shek Kip Mei Syndrome, Economic development and public housing in Hong Kong and Singapore, Pion Ltd., 1990.

16) Segbers, K.(edit), Patel, S. Hoskote, R. Phatak, V. K.: The Making of Global City Regions, Johannesburg, Mumbai / Bombay, Sao Paulo, and Shanghai, The Johns Hopkins University Press, 2007

17) Census of India 1901, Bombay Presidency, District Census Handbook, 1901

18) Census of India 1931, Bombay Presidency, District Census Handbook, 1931

19) Dossal, M.: Imperial Designs and Indian Realities, The Planning of Bombay City, 1845-1875”, Oxford University Press, 1991

20) Basu, D. K.: The Rise and Growth of the Colonial Port Cities in Asia, University of California Press, Berkley, 1985

21) Patel, S., Masselos, J.: Bombay and Mumbai, The city in transition, Oxford University Press, 2003

22) Mukhija, V.: Squatters as Developers?, Slum redevelopment in Mumbai, Ashgate, 2003

23) Bombay A Photorama, Photographic exhibition about the rise and growth of Bombay from the year 1661 to 1931, Municipal Corporation of Greater Bombay, 1981

24）ノールス, L. C. A., 岡倉古志郎・前林正二（共訳）：英国植民地経済史， 有明書房, 1997 (原著出版, 1944)

25）飯塚キヨ：植民都市の空間形成, 大明堂, 1985

26) Richards, E. P.,: The Condition, Improvement and Town Planning of the City of Calcutta and contiguous areas, Report by request of the Trust, Calcutta City Improvement Trust, 1914

27) Orr, J. P.: The Bombay City Improvement Trust from 1898 to 1909 , Times Press, 1911

28）池尻隆史, 安藤正雄, 布野修司, 山根周, 片岡嚴: ネイティブタウン（イン ド・ムンバイ）のコミュニティー構成に関する研究”, 日本建築学会計画 系論文集,No.589, pp.219-226, 2005.12

29）池尻隆史, 安藤正雄, 布野修司, 山根周, 片岡嚴 : ネイティブタウン（イン ド・ムンバイ）におけるチョールの類型に関する研究, 日本建築学会計画 系論文集 ,No.603, pp.37-44, 2006.5

30）池尻隆史、重冨惊一,“ムンバイ（インド）の改善チョールとその変容に 関する研究”, その 1 改善チョールの形成とトラストの活動, 日本建築学 会大会学術講演梗概集,F-1 分冊, pp.849-850, 2004

31）重冨惊一、池尻隆史, “ムンバイ（インド）の改善チョールとその変容に 関寸る研究”, その 2 改善チョールの現状と特性, 日本建築学会大会学術 講演梗概集,F-1 分冊, pp.851-852, 2004

注

注 1）ムンバイ Mumbai はかつてボンベイ Bombay を指す。これは 1990 年 代に改称されたもので、この頃は同様にインド各地において植民地期 の都市名や街路名など改称される例が多かった。本論文中の歴史的呼 称に関してはボンベイを用いる。

注 2）チョール Chawl はムンバイにおいて代表的な都市住宅の類型である。 基本的に便所と水廻り設備を共有し、単室ないしは複室の狭小貸間か ら構成される集合住宅である。一般に $3 \sim 5$ 階でその居住密度は極め て高く、市内の旧現地人居住地（現在の Ward B および C を中心とす る)の住居建築の多くを占める。その空間構成の類型や、居住者のコミュ ニティーの実態に関しては拙著論文を参考されたい（参考文献 28 およ び 29)。BITチョールとはBIT が建設したチョールという意味で、現 地では名称として一般化している模様である。

注 3）植民地期のインドにおける都市改善トラストは、ボンベイに続きマイ ソール（1903 年)、カルカッタ（1911 年)、ハイデラバード（1912 年)、デリー（1919 年）などに設立され、最終的にバンガロール（1945 年）やマドラス（1946 年）にも設立された。独立以降はラジャスタ ン州などで設立の実績があるが、組織の存続状況については Housing Development Board など他の組織に吸収される例もあり、様々である。 旧英国植民地においては 1927 年にシンガポールにおいて設立の例があ
るが現在は住宅開発庁に発展解消している（1960 年）。

注 4）文部科学省科研費・若手研究 (B) 2009 ～(研究代表者 池尻隆史)。本 研究は旧 BIT による住宅供給事業を対象に、関連する歴史的資料と現 況の実測調査によって、供給された住宅群の建築計画的特性を明らかに すると共に、その歷史的位置づけを明確にすることを目的とする。仮説 的にアジア地域における公的住宅供給の成立は旧植民都市に始まる可 能性が指摘できるが、ボンベイの事例はその中で最も早い事例の一つと 目され、ここで成立した建築形態が各地に伝播した可能性が高い。この 伝播の様態の検証は、BIT の事績を位置づける上で大きな意味を持つ。

注 5) BIT の年次報告書は British Library (London, UK) に全冊が系統的 に保存されており閲覧可能である。本論文では基礎史料として、この British Library 所蔵のものを利用した。

注 6）参考文献 2）から 4）の文献からはBIT チョールの仕様や供給過程に関 する記述が多く含まれる。特に Hurst による参考文献 2) ではBIT の活 動のうち初期から中期にかけての建設事例とその背景に関する記述が 多くあり、Upadhyay による参考文献 4) には年次報告書中で記述の少な い工場チョールの建設経緯に関する詳細な記述がある。

注 7） BIT チョールの図面類については、年次報告書に収蔵されているもの の他は入手できていない。登記簿については、現在のものについて一 部確認できたが、いずれも配置図レベルで住棟の外形と住戸の位置を 示したもので、各部の詳細に関する情報の抽出については困難である。

注 8) MMRDA は Mumbai Metropolitan Region Development Authority を 指す（かつての BMRDA）。都市計画図は「Sanctioned Development Plan 1981-2001」と題するものでムンバイの行政区（Word A から F の 6 区）ごとに地区の現状と改善計画が地図上に示されている。縮尺 は $1 / 2500$ で出版年は 1995 年である。

注 9） 2003 年時の調査記録を用いたのはプリンセス・ストリート Princess Street の事例のみである。

注 10) Home が指摘する通り、当時のセンサスによれば 1891 年に 821,764 人を数えた都市の人口が 1901 年には 776,006 人にまで減少している。 これはペストの流行が主原因とされ、特に 1896 年末には 1 週間当り 1900 人におよぶ死者が出たとされる（Edward, 1906, vol.3, p174およ びMehrotra, 1995, p165 など)。このペストの蔓延により、住民の逃散 も起こり、都市経済に打撃を与えるとともに、周辺地域への伝播の原因 となった（Home, 1996, p74）。ペストはこの時代のインドにおいて猖獗 を極め、1869 年から 1914 年にかけて推計 700 万人が死亡したとされる。

注 11）トラストは改善トラスト委員会 Improvement Trust Board によって 運営された。委員会は理事長を含む 14 人の理事から構成され、徵税 官 The collector of Land Revenue, Customs and Opium や市参事会会 長 The Municipal Commissioner さらに高級軍人 The General Officer Commanding の名前が記録にある。その他の委員は市当局 Corporation や、商工会議所 Chamber of Commerce、港湾トラスト Port Trust、工場 主協会 Mill Owner's Association などの推挙による（BIT, 1898）。

注 12) “the work of making new streets, opening out crowded localities, reclaiming lands from the sea to provide room for the expansion of the City and constructing sanitary dwellings for the poor" (BIT, 1898)

注 13）付託された土地の面積は 1908 年までに $3 \mathrm{~K} \mathrm{~m}^{2}$ に達した。またトラストは 税収から寄付金を支給されており、1900 年度には税収の $6 \%$ 弱に当たる 475,000 Rs/- といら額が記録されている（Edward, 1906, vol.3, pp87-90)。

注 14)この種の事業計画としては Wellington Lines (Scheme No. 20) や Hornby Road (No. 22) などが挙げられる。いずれもかつてフォート地 区の外縁にあった城壁の跡地を含む土地に計画されたもので、現在も 計画当時の整然とした区画割りを維持している。

注 15）BIT 設立以前のアグリパーダ地区は湿地帯が広がり、競馬場が設置さ れている他はバンガローが点在する未開発地であった。BIT はこの地 区の埋立て、後の市街地改良に伴う移転地として積極的に整備した。

注 16）郊外における新規街路および住宅地の開発については Scheme No.5お よびNo.6の Dadar から Sion にかけての計画が代表的である。Parel 以北の南北街路は King Way と名付けられ、大規模なラウンド・ア バウトと放射状の街路計画を組夕合わせた大規模な地区開発が行われ た。特にDadar 以北では当時のボンベイで経済的に大きな力を持った パースィーの一大コミュニティーが形成され、現地人の都市富裕層の 
住宅地となった。中流階層以下の居住地開発に関してはウォルリWorli (Scheme No.52 および 58、他) の例が大規模である。

注 17）警察官官舎は独立した事業として計画されているが、BITによる開 発地に隣接して建設される例が多い。警察官官舎はフォート地区から 北部郊外の Dadar 地区に至るまで、市内の各地で建設が確認できる。 Wode-House Road (Scheme No.16) や Connaught Road (Scheme No. 25)、また 2nd Naigaum (Scheme No.67) などは大規模な例である。

注 18）BITによる住宅事業はチョールの他、市街地再開発に伴う一時的住宅 である Temporary Hut や前出の警察官宿舎が挙げられる。これらを合 わせると、BIT による総供給住宅数は概算で 3 万戸余りに達する。

注 19）年次報告書中では主に “poor and working classes” と表記されている。

注 20）倉庫は現地言語でグダン Godown と呼ばれ、年次報告書中でもこの名 称が使用されている。特にチンチバンダルの事例では、一階部分が明 確にグダンとして計画されている。

注 21）BIT は工場労働者用の衛生的チョールの建設を目指し、1900 年にはす でに工場主協会との交涉を開始している。焦点は建設費および維持費 の負担割合に関寸るもので、交渉は難航し決裂した。交渉が再開され たのは 1909 年のことであり、1916年にようやく合意にこぎ着け、チョー ル事業の認可に至った (Upadhyay, 2004, pp72-75)。

注 22）年次報告書には明記されていないが、このマハールコミュニティーとは おそらくムンバイを含むマハーラーシュトラ州において一大集団を成す 指定カース卜集団である。現状でこのチョールの敷地内には新仏教徒寺 院が併設されており、この集団が継続的に居住していることが賽える。

注 23）年次報告書によれば、この他にカラパニ Karapani チョールはムスリムの 織物工場労働者の住宅として計画されたという記述がある (BIT, 1921)。

注 24）ピオン Peon とは現地語で、一般に“雇われ人”を意味する。

注 25）ここでいう主体構造とは「主要な構造部分」を指す。年次報告書中で は構造種に関して RC やレンガの使用に関する記述はあるものの、そ の具体的な適用箇所に関しては記述がない場合も多い。

注 26）これ以前のチョールについても、コンクリートの使用に関寸る記述が 残っている。たとえばアグリパーダ A チョールは当初戸境壁をコン クリートで計画したが、経済的見地からレンガ造に改められた（BIT， 1899)。また、当初レンガ造で建設されたものの、その後一部を RC に よって改築するものがあった。

注 27）アグリパーダ A および Bチョール（報告書中では Agripada Chawls と 記載されている）における死亡率は人口 1000 人当り 61.31（1906 年） から 29.08 (1907 年度) へと変化しているが、竣工後時間が経過した時 点での数值であり、直接的な効果については疑問の余地がある (Agripada Bチョールは 1903 年の竣工)。他のチョールではチャンダンワディ Chandanwadi で 36.41、ナグパーダ A で 31.44 という数值が残ってい る（BIT, 1907）。ただし同年のフォートや人口希薄地帯を含む都市全体 の死亡率は 39.56 となっており、BIT チョールの数值はこれに比して低 いものであったことは確かである。

注 28) “... Their value is realized when we find that the death-rate in the Trust Chawls is from one-third to one-quarter of that of the whole city..."( Hurst, 1925, p26)

注 29) Chandavarkar によれば、1918 年までにトラストの改善施策は 64000 人の住民の転居を要したが、再居住できたのはそのうち 14000 人程度 に過ぎなかった（Chandavarkar, 1994, pp175-178)。Hurstによる推 計では、これよりも好意的な数值が示されている（Hurst, 1925）。

注 30) Upadhyayによれば、チョール建設に対する工場主の協力は限定的で 76 の工場のうち 22 の工場のみが建設に同意した。これらの労働者の 総数はおよそ 64000 人であったが、建設されたチョールに住むことが できたのは $20 \%$ 程度に過ぎなかった（Upadhyay, 2004, p73）。

注 31）1920 年にボンベイ州政府 Government of BombayはBIT とは別の組 織である Development Department を通じて 50000 戸に及ぶ工場労働 者向け住宅供給計画に着手した。しかしながら、実際の供給量は 16000 戸余りに留まり、また建物の仕様や立地から入居率が振るわなかったこ となど、こちらも多くの問題を抱えていた。これらのチョールは BDD Chawl と呼ばれ、市内の Worli 地区、Naigaon 地区、またパレル地区 に多くが現存する。

注 32) 図中(13)のスプリングミルチョールと(19)コーヒヌールミルチョールが工
場チョールに当たる。(21)センチュリーミル Century Mill チョールと(22) デーヴィッドミル David Mill チョールも工場チョールである可能性が 高いが、文献における記述が限定的であること、また現況調査から判 断して現存する建築物が BIT チョールであるか否かに関する確証が得 られなかったため、本論文においては分析の対象としていない。

注 33）かつてのピオンズチョールと推定される地所では、現在建築工事が進 展中であり、おそらく再開発が行われているものと思われる。

注 34）取り壊した跡地の一部には「トランジットキャンプ」と呼ばれる仮設 の大型住棟が建設されている

注 35) Imamwada チョールでは、既存棟間の余地にトランジットキャンプの 建設が進行中である (2009 年現在)。トランジットキャンプの完成・ 入居以降、既存住棟の取り壊しが始まる予定である。

注 36）フォラスロード Foras Rd チョールでは複数の場所に開発計画のポスター が貼られ、住民に対する事業説明集会もすでに開催されている模様である。

注 37）現地調査時には、いずれの事業地でも住民が建替え事業の存在につい て言及することが多かった。住居の仕様が大幅に向上するため、基本 的に建替計画は歓迎されている印象であるが、一方で反対意見も多い 模様であり住民間の対立が懸念される状況にある。

注 38）イマームワダの事例では建物の垂直加重を受ける柱ならびに壁がレン ガ造で梁やスラブといった水平材に RC を用いる混構造となっている。 アグリパーダ B チョールも同様の構成であり、この種のチョールはお そらく同様の構成を持つと考えられる。本稿では垂直材部分の構造に 着目して、これらを「レンガ造」と表記している。これを含む構造部 材の詳細などの構法的な性状に関する議論は別稿に譲りたい。

注 39）年次報告書によれば、現存していないピオンズチョールは片廊下型の 住戸配置で計画されたとのことである。

注 40）マザガオン Mazagaon やフォラスロードの事例では、一部独立した独 立した便所棟を持つチョールも建設されているが、いずれも大部分は 「棟間・集中」型となっている。

注 41）その他の類型としては 1 棟のみの単独で建つプリンセスストリート Princess Streetチョールの例がある。

注 42）拙著、参考文献 29）他を参照のこと

注 43）クンバルワダ Kumbarwada 地区はパレル・ロード Parel Road をはさ んでイマームワダ・チョールの西側に隣接する地区であり、地区の建 物の約 7 割をチョールが占める。

注 44）コーヒヌールミルチョールの建設過程について年次報告書を精查する と、1913 年に事業に先立つ交渉が開始され、1919 年に認可されている。 その後のチョールの仕様に関する記述では当初からシングル・チョー ル、すなわち片廊下型の計画であることが示されているが、このよう な形式の採用に至る過程に関する記述はない。ただし、このチョール に関しては、居住環境の向上のために複数居室 double room とするこ とが明記されており、片廊下型の計画もこの居住環境の向上を目指寸 意図で企画された可能性がある。結局のところ、工場主との交涉の不 調に伴う資金の不足により、複数居室のチョールは全体の $1 / 4$ 程度し か建設されなかった（BIT, 1913-1922）。このコーヒヌールミル・チョー ルに関しては、設計に関わる具体的な資料が収蔵されていないため、 建築形態に関する議論の展開が困難である。図面の収集や現状の実測 などを行う必要がある。

注 45）現状では、郊外に点在したかつての大工場の多くはすでに操業を停止し ており、その跡地において大規模な再開発が行われている。これらに隣 接する旧 BIT チョールは、面的開発に耐えるまとまった敷地を有してい るという点で貴重な存在であり、次の開発対象として有望視されている 状況である。

注 46）この観点から、すでに取り壊しが進行中ないしは確定的なアグリパー ダの 3 事例とイマームワダの事例については、すでに住棟の実測調査 を行った。これについては発表の機会を改めたい。

注 47）情報収集のため、INTACH (The Indian National Trust for Art and Cultural Heritage) Greater Mumbai 事務所にてヒアリングを行った が、BITチョールに関しては特段の調査を行っておらず、また今後も その予定はないとのことであった。

（2010年 1 月 8 日原稿受理，2010年 5 月 12 日採用決定） 